\title{
A Review on Polyherbal Formulations used in the Treatment of Autoimmune Disease like Rheumatoid Arthritis
}

\author{
Ankur $^{1}$, Anjali $^{1}$, Ajit Singh ${ }^{1}$, Abhiranjan ${ }^{1}$, Akash $^{1}$, Kalpana Garg ${ }^{1}$, Anurag Bhargava ${ }^{1}$, Sakshi \\ Bajaj \\ ${ }^{1}$ CH. Devi Lal College of Pharmacy, Jagadhri- 135003, Haryana \\ E-mail: gargkalpana06@gmail.com
}

\begin{abstract}
This article presents about various Polyherbal formulations utilized in arthritis Treatment. Rheumatoid arthritis being a progressive disease causes inflammation in joints and resulting in painful Deformity and immobility especially within the finger, wrist, feet and ankles. It belongs to Non-Organ specific class of Auto immune diseases. Autoimmune disorder is an illness that happens when body tissue is attacked by its own system. Consistent with Ayurvedic principles, PHF is that the one which contains two or more herbs within the formulation which acts synergistically. The herbal plants having ethno-medicinal values are currently being screened for their therapeutic activities. Further the article represents various RA based PHF and thus the Marketed formulation available for it.
\end{abstract}

Keywords: Ayurvedic principles, Polyherbal formulation, autoimmune diseases, Rheumatoid arthritis, ethno medicinal.

\section{Introduction}

\section{Polyherbal formulation}

Polyherbal formulation (PHF) is that when more than one herb is used during a medicinal/therapeutically preparation. This concept is derived from Ayurvedic and other traditional medicinal systems where multiple herbs within a particular ratio could also be utilized in the treatment of diseases. [1] The Ayurvedic literature "Sarangdhar Samhita" dated centuries ago in 1300 A. D. has highlighted the concept of polyherbalism during this ancient medicinal system. Within the traditional system of Indian medicine, plant formulations and combined extracts of plants are chosen instead of individual ones. 


\section{Autoimmune diseases}

Disorders of Immune system cause abnormally reduced activity or over activity of the system. In cases of system over activity, the body attacks and damages its own tissues (autoimmune diseases). Immune deficiency diseases decrease the body's ability to fight invaders, causing vulnerability to infections. In response to an unknown trigger, the system may begin producing antibodies that rather than fighting infections, attack the body's own tissues. Treatment for autoimmune diseases generally focuses on reducing system activity. [2]

\section{Common Autoimmune Diseases}

There are quite 80 different autoimmune diseases. Here are a number of the foremost common ones. [2, 3]

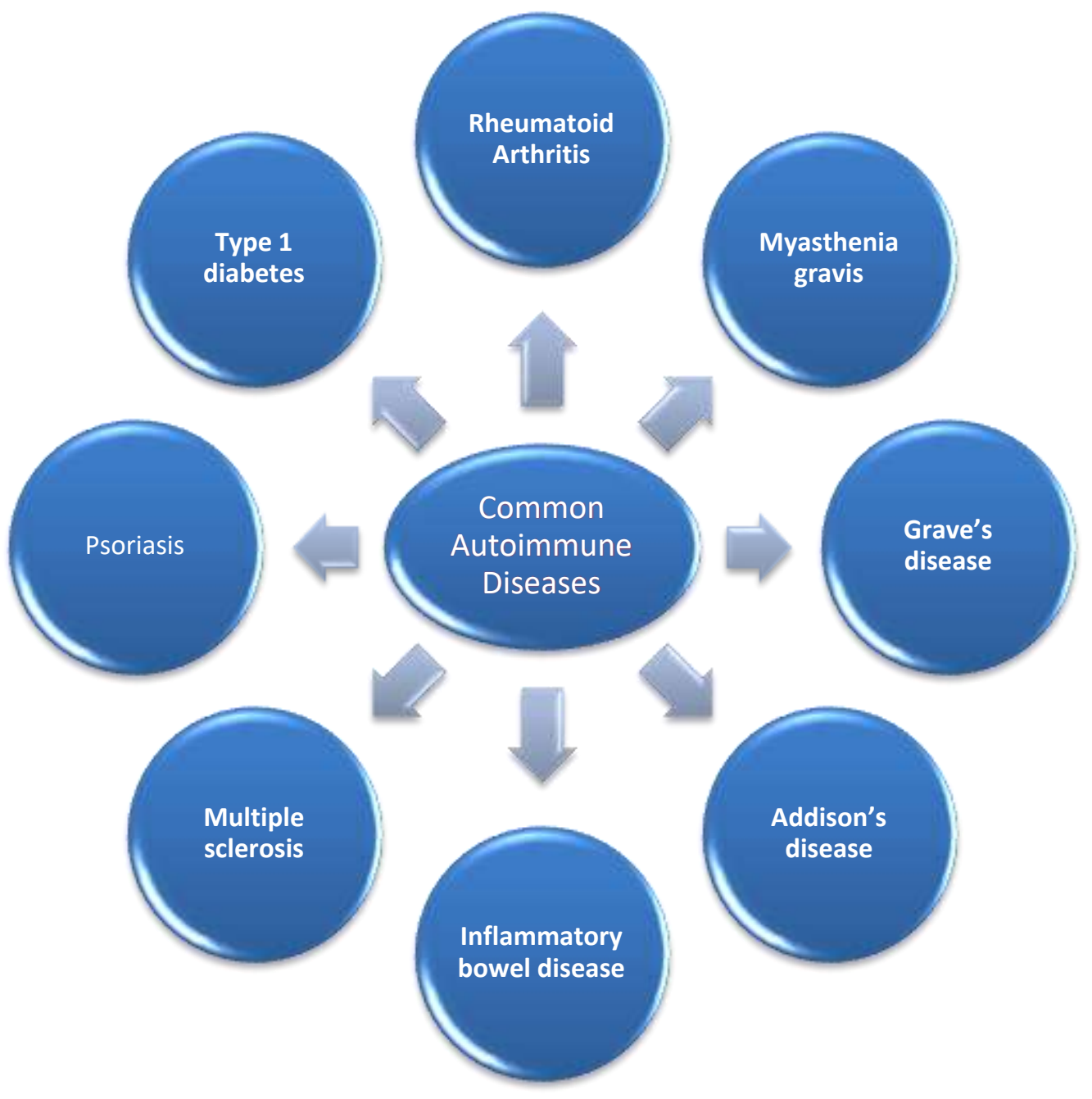


Type 1diabetes: The pancreas produces the hormone insulin, which helps regulate blood glucose levels. In type $1 \mathrm{DM}$, the system attacks and destroys insulin-producing cells within the pancreas. High blood sugar results can cause damage within the blood vessels, also as organs a bit like the heart, kidneys, eyes, and nerves.

Psoriasis/psoriatic arthritis: Skin cells normally grow and so shed when they're not needed. Psoriasis causes skin cells to multiply too quickly. The additional cells build up and form inflamed red patches, commonly with silver-white scales of plaque on the skin. Up to 30 percent of individuals with psoriasis also develop swelling, stiffness, and pain in their joints. This type of the disease is known as rheumatoid arthritis.

Multiple sclerosis: Multiple sclerosis (MS) damages the myelin sheath, the protective coating that surrounds nerve cells, in your central nervous system. Damage to the myelin sheath slows the transmission speed of messages between your brain and spinal cord to and from the rest of your body. This damage can cause symptoms like numbness, weakness, balance issues, and trouble walking. Consistent with a 2012 study Trusted Source, about 50 percent of people with MS need help walking within 15 years after the disease starts.

Inflammatory bowel disease: Inflammatory bowel disease (IBD) could also be a term used to describe conditions that cause inflammation within the liner of the intestinal wall. Each kind of IBD affects a special a neighborhood of the alimentary tract. Crohn's disease can inflame any a neighborhood of the alimentary tract, from the mouth to the anus. Ulcerative colitis affects only the inner lining of the massive intestine (colon) and rectum.

Addison's disease: Addison's disease affects the adrenal glands, which produce the hormones cortisol and aldosterone also as androgen hormones. Having insufficient of cortisol can affect the way the body uses and stores carbohydrates and sugar (glucose). Deficiency of aldosterone will cause sodium loss and excess potassium within the bloodstream. Symptoms include weakness, fatigue, weight loss, and low blood glucose.

Grave's disease: Grave's disease is an autoimmune disease in which immune system attacks the thyroid within the neck, causing it to provide an excessive amount of its hormones. Thyroid hormones control the body's energy usage, mentioned as metabolism. Having an excessive amount of these hormones revs up your body's activities, causing symptoms like nervousness, a fast heartbeat, heat intolerance, and weight 
loss. One symptom of disease is bulging eyes, known as exophthalmos. It can occur as an area of what is called Graves' ophthalmopathy, which occurs in around 30 percent of those who have Graves' disease, according to a 1993 study.

Myasthenia gravis: Myasthenia gravis affects nerve impulses that help the brain control the muscles. When the muscles-nerves communication is impaired, muscles contraction is hindered. The foremost common symptom is muscle weakness that gets worse with activity and improves with rest.

Rheumatoid Arthritis: Rheumatoid arthritis (RA) is an autoimmune disease which can cause joint pain and damage throughout your body. If a joint is affected among your arms or legs on, an equivalent joint within the other arm or leg will probably be affected, too. This is often a method that doctors distinguish RA from other sorts of arthritis, like osteoarthritis (OA) the joint damage that RA causes usually happens on each side of the body. So, if a joint is affected in one among your arms or legs, an equivalent joint within the other arm or leg will probably be affected, too. This is often a method that doctors distinguish RA from other sorts of arthritis, like osteoarthritis (OA). [3] Rheumatoid arthritis generally affects body joints, but it also affects some other organs in more than $15-25 \%$ of cases. [4] Which includes osteoporosis, cardiovascular disease, cancer, interstitial lung disease, mental difficulties, infection, trouble working feeling tired, and depression [5]
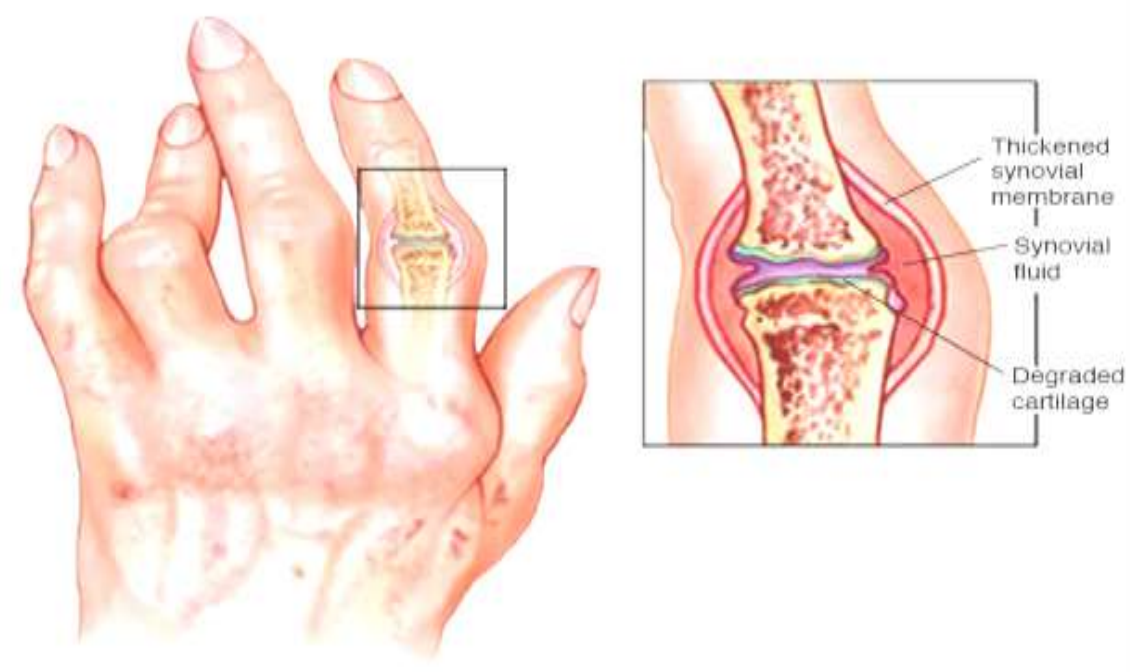

Figure 1 Rheumatoid arthritis in finger joint 


\section{Rheumatoid arthritis progress in three stages}

Stage 1: Swelling of synovial lining, causing pain, warmth, stiffness, redness, swelling around the join Stage 2: Rapid division and growth cell, or pannus, which cause the synovium to thicken.

Stage3: The inflamed cell releases enzyme that may digest the bone and cartilage,

\section{Often Some of the Commercially Available PHF for Rheumatoid Arthritis}

Rumalaya Forte-Tablet (Himalaya Global Holdings Ltd.),

Rumalaya-Liniment (Himalaya Global Holdings Ltd),

Artha cure-Oil (Be Sure Health Care (P) Ltd),

Arthacure-Capsule (Be Sure Health Care (P) Ltd.),

Rheumartho Gold - Capsule (Baidyanath),

Ortho Joint Oil- (SBS Biotech ltd).

Rheuma off Gold- (Virgo UAP Pharma (P) Ltd.

Symptoms: body ache, tastelessness, Excessive thirst, lethargy, heaviness in body, feverishness early morning stiffness in the joints, Pain in the joints (similar to the pain as stung by a scorpion). Apart from these symptoms it includes extra-articular features like nodules, pericarditis, pulmonary fibrosis, peripheral neuropathy amyloidosis.

\section{Herb-Herb Combinations}

Herb-herb combinations also known as Polyherbal therapy have been used in Chinese medicine practice for thousands of years, yet scientific evidence of their therapeutic benefits is lacking. Drug combination often produces promising effect in treatment of diseases over a single drug. The concept of drug combination has been well established in Western medicine and memorable success has been achieved over the past few decades. In recent years, drug combination therapies in cancer and infectious diseases have offered new hope to patients suffering from these diseases. [6, 7] Naturally occurring herbs and herbal ingredients organized into certain formula have been shown to have potential interaction effects. These include mutual enhancement, restraint, assistance and mutual antagonism. In the Ayurvedic system of medicine mainly Polyherbal compounds are used for treatment of various infections. Ayurveda suggests that the arthritis occurs due to imbalance of Vata. Chopraet al., reported around $68 \%$ patients with chronic rheumatic disorders has sought relief using alternative system of medicines. [7, 8] 


\section{Factors Affecting Polyherbal Formulation}

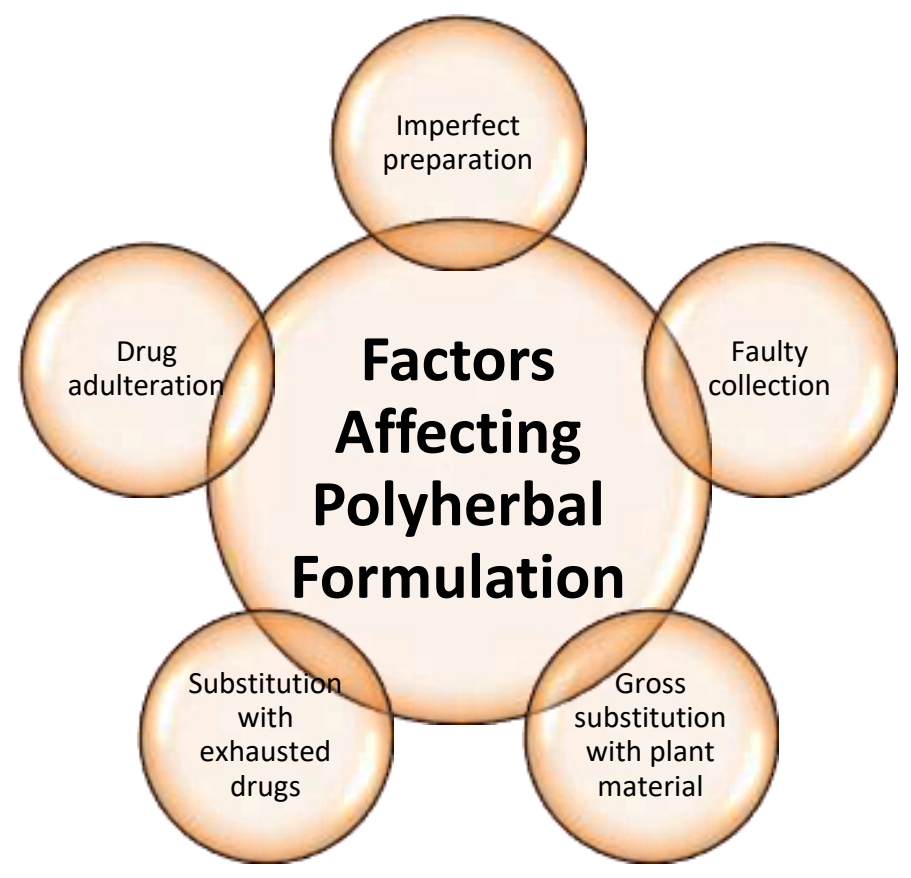

\section{Methods and types of polyherbal formulations}

Natural fermented liquid medicines - Medicinal preparations processed by soaking drugs within the powdered forms or within the sort of their decoction (known as kasaya in Ayurveda), during a solution of sugar or jiggery (Gur), for a specified period of time. [9] During soaking, it undergoes fermentation generating alcohol and in process facilitating extraction of active constituents contained in the drugs.

Fumigation - The fermentation vessels are subjected to dhoopana, a process of fumigation to stop the expansion of present microorganisms which will contaminate or hamper the method of fermentation. [10] Molasses or powders of crude drugs like Indian valerian, agar (Aquilariaagallocha), chandan (Santalum album), marich (Piper nigrum, Black pepper) and such are sprinkled on hot embers and burnt to fumigate. These crude drugs may contain volatile oils that have antibacterial, antiseptic action thereby providing a selected eco- system almost like present day sterilization. [10, 11]

Smearing and Coating Process- The fermentation vessels are porous to outside air that may affect fermentation process. Smearing and coating of the inner surface of vessel is performed to eradicate adverse effects. [12] Ghee, honey or cow's urine are used as base with herbs like Pippali (long pepper) Chavya (Piper retrofractum), Priyangu (Callicarpa macrophylla) made into the form of paste that is 
smeared evenly to give a coating on the inner surface of vessel. [12] Such a coat forms protective layer to prevent any unwarranted interaction between the fermentation material and outside air. Most of the ingredients that are used for smearing and coating process have some very pungent or sharp attributes.

Fermented decoction- The crude drugs mentioned within the formula (patha), are coarsely powdered and decoction (Kashaya) is ready, filtered and transferred to wooden vats. Sugar, honey or jiggery is added there which is then dissolved and boiled. [13] Dravyas, other finely powdered ingredients and Dhataki pushpa (Woodfordica fruticose) are added to it to trigger the fermentation process. [14]

Medicated clarified butters-The preparation during which ghee is boiled with the prescribed quantity of the decoction (Kashaya) and fine paste (Kalka) of the drug as laid out in the formula. The process of preparation of ghrita ensures the absorption of the therapeutically active constituents of the drugs utilized in the preparation. Ghrita solidifies when cooled. It has color, odor and taste of the ingredients used in the preparation. [15]

Powders-Fine powder of drug or drugs is known as churna. Drugs mentioned within formula, are cleaned, dried, pulverized and the sieved properly and thoroughly. [16] The churna is free flowing and retains potency for one year, if preserved in air-tight containers. Examples are - Trikatuchurna, Drakshadichurna, Triphalachurna, Sudarshanchurna, and Sitopaladichurna. [16, 17]

Detoxification of Formulation- Detoxification simply means removal of toxins; Ayurveda involves the utilization of drugs obtained from plants, animals, and mineral origin. All these 3 sources of drugs can be generally divided under poisonous and non-poisonous category. Various crude drugs generally possess considerable amount of unwanted impurities and toxic substances, which can lead to harmful health related problems. These poisonous/toxic plants are categorized as visa (poison) and upavișa (toxic but not lethal for human health) in Ayurvedic texts and also in the Schedule-E of Drugs and Cosmetics Act 1940. [18]. The process used detoxification or purification of any toxic material used for medicinal purposes is termed as "Śodhana". Śodhana (detoxification/purification) involves the conversion of any poisonous drug into beneficial, non-poisonous/nontoxic ones. [19]

\section{Kashayams}

Toll-like receptor-4 (TLR-4) mediates activation of nuclear factor kappa-light-chain-enhancer of activated B cells $(\mathrm{NF}-\kappa \mathrm{B})$ resulting in induction of pro-inflammatory genes such as that encoding tumor necrosis factor- $\alpha$ (TNF- $\alpha)$ and interleukin-1 $\beta$ (IL-1 $\beta)$ which plays a remarkable role in cartilage demolition of rheumatoid arthritis (RA). [20] Low risk and better efficacy made herbal drugs more reliable than no 
steroid anti-inflammatory drugs (NSAIDS) in RA treatment. Gugguluthiktam Kashayam (GuK), Punarnavadi Kashayam (PuK) and Balaguluchiadi Kashayam (BgK) are Ayurveda Polyherbal formulations prescribeed in classical Ayurvedic texts Sahasrayogam and Ashtangahridayam as medicines for therapy of Rheumatoid arthritis. Immunomodulatory properties of Tinospora cordifolia, an essential herb of three kashayams and also Indian bdellium, Azadirachta indica, Justicia adhathoda which forms the components of GuK. [20, 21] Balaguluchiadi Kashayam consists of 10 herbs including Sida cordifolia, Adenanthera pavonina, Cedrus deodara whose anti-inflammatory properties have been evidenced while Punarnavadi Kashayam was made from 6 plants like Boerhavia diffusa, A. indica, Adhathoda vasicca. Etc. [22] Balaguluchiadi, Punarnavadi and Gugguluthiktam Kashayams are recommended Ayurvedic classical medicine used in the treatment of rheumatoid arthritis but scientific data regarding its molecular mechanism of action is not yet available. Kashayams $\mathrm{PuK}, \mathrm{BgK}$ and $\mathrm{GuK}$ functions as potent anti-inflammatory drugs by inhibiting TLR-4 MYD88 dependent signal transduction pathway in plasma membrane. The balance between pro-inflammatory and anti-inflammatory cytokines, its synthesis and secretions were maintained thereby regulating chronic inflammation. [23]

\section{Arthosansar}

Arthosansar is a polyherbal drug which is found to be more effective as anti-arthritic with less or no side effects. Arthosansar is a polyherbal formulation developed by Pradhan Herbal Company, Bangalore, containing 7 plant constituents, viz. Guggulu (Commiphora wightii Arn.), Sallaki (Boswellia serrata Roxb.), (Pluchea lanceolata), Eranda (Ricinu scommunis Linn.), Shunti (Zingiber officinale), Shilajit (a gummy substance found in the rocks of certain mountainous regions of the world) and Aswagandha. [24] The mechanism of action is explained by emphasizing on immunomodulation, anti-inflammatory and analgesic action. The study is carried out using CFA induced arthritis in rats, carrageenan induced peritonitis in mice, inflammation induced by various phlogistic agents in rats, and acetic acid induced writhing in mice and tail-immersion test in mice. [25] The pathogenesis of RA involves an aberrant immune response that leads to synovial inflammation and destruction of joint architecture Inflammation Is divided into 3 phases: acute inflammation, acute inflammation is the initial response to injury, mediated by the release of autacoids and usually precedes the development of the immune response. The immune response is seen when immunologically competent cells are activated. [26] The outcome of the immune response leads to chronic inflammation that results in pain and destruction of bone and cartilage.CFA induced arthritis in rats, CFA act by prolonging the life time of injected auto antigen, by stimulating its effective delivery to the immune system and by providing a complex set of signals to the immune system, results in decreased leukocyte proliferation and differentiation that causes increased phagocytosis and 
secretion of cytokines by mononuclear phagocytes. Biochemical estimation of serum aminotransferases indicated that CFA increased levels of Aminotransferases. The increase in aminotransferases is due to their release from the cells of the damaged organ, since liver impairment is a feature of adjuvant arthritis. [27] Arthosansar significantly reduced the serum aminotransferases levels. This effect is due to its antiinflammatory and anti-oxidant property that prevents organ damage. [28] It is postulated that during inflammation, the mediators released, histamine, bradykinin and prostaglandins increase the permeability of vascular tissues to albumin leading to reduction in its serum levels12. [29] Thus treatment with arthosansar significantly reduced the increased plasma protein levels, i.e., decreased the globulin levels and increased the albumin levels in arthritic rats which indicates that Arthosansar have a suppressive action on the mediators of inflammation. [30] It is proposed that, Arthosansar exhibit anti-arthritic action by following mechanism:

1. Inhibits lymphocyte proliferation primarily T-helper cells (Th1).

2. Inhibits production of IF- $\gamma$, TNF- $\alpha$, IL- 2 by Th 1 cells.

3. Inhibits release of inflammatory mediators (PGs, Histamine, 5-HT and bradykinin) thus prevents mononuclear infiltration and pain mediated by these mediators.

4. Exhibits ant nociceptive action through opioid receptors and by promoting release of endogenous peptides

For its anti-arthritic activity may be attributed to its different plant components. Boswellia serrata consists of Boswellic acid which reduces the synthesis of leukotrienes in intact neutrophils by inhibiting 5-lipoxygenase enzyme. Also cause immunomodulation by simultaneously inhibiting TH1 and pro study was taken up with the aim of elucidating the mechanism of anti-arthritic action of the formulation. [31] The data generated in these study/results will provide a scientific evidence/basis to prove the efficacy of the ayurvedic formulation. To common people, it is validation of claim of the formulation as a drug in treatment of arthritis. For researchers, it proposes as well as proves the underlying mechanism of action of Moting TH2 cytokine production. [32] It reduces the glycosaminoglycan degradation, essential to prevent articular damage. Zingiber officinale Linn. Has inhibitory effects on COX-2 enzymes and it attenuates COX-1/ thromboxane synthase enzymatic activity [32, 33]. Withania somnifera Dunal, also known as ashwagandha inhibits delayed-type hypersensitivity reactions and suppresses enhanced phagocytic activity of macrophages. It also reduces the glycosaminoglycan degradation. [34] Commiphora wightii Arn, the main ingredients of Commiphora wightii are flavonoids which have potent anti-oxidant actions and are reported to inhibit nitric oxide formation. [35] Ricinius communis Linn. Possess analgesic effect and also are effective in both acute and chronic inflammation [35, 36]. Shilajit Research supports the use of shilajit and in rheumatism. Commiphora wightii Arn. And shilajit, are reported to be effective in 
experimental arthritis induced by mycobacterium adjuvant. The ayurvedic product is based on the ancient Indian text for alleviation of pain associated with arthritis. [38] 


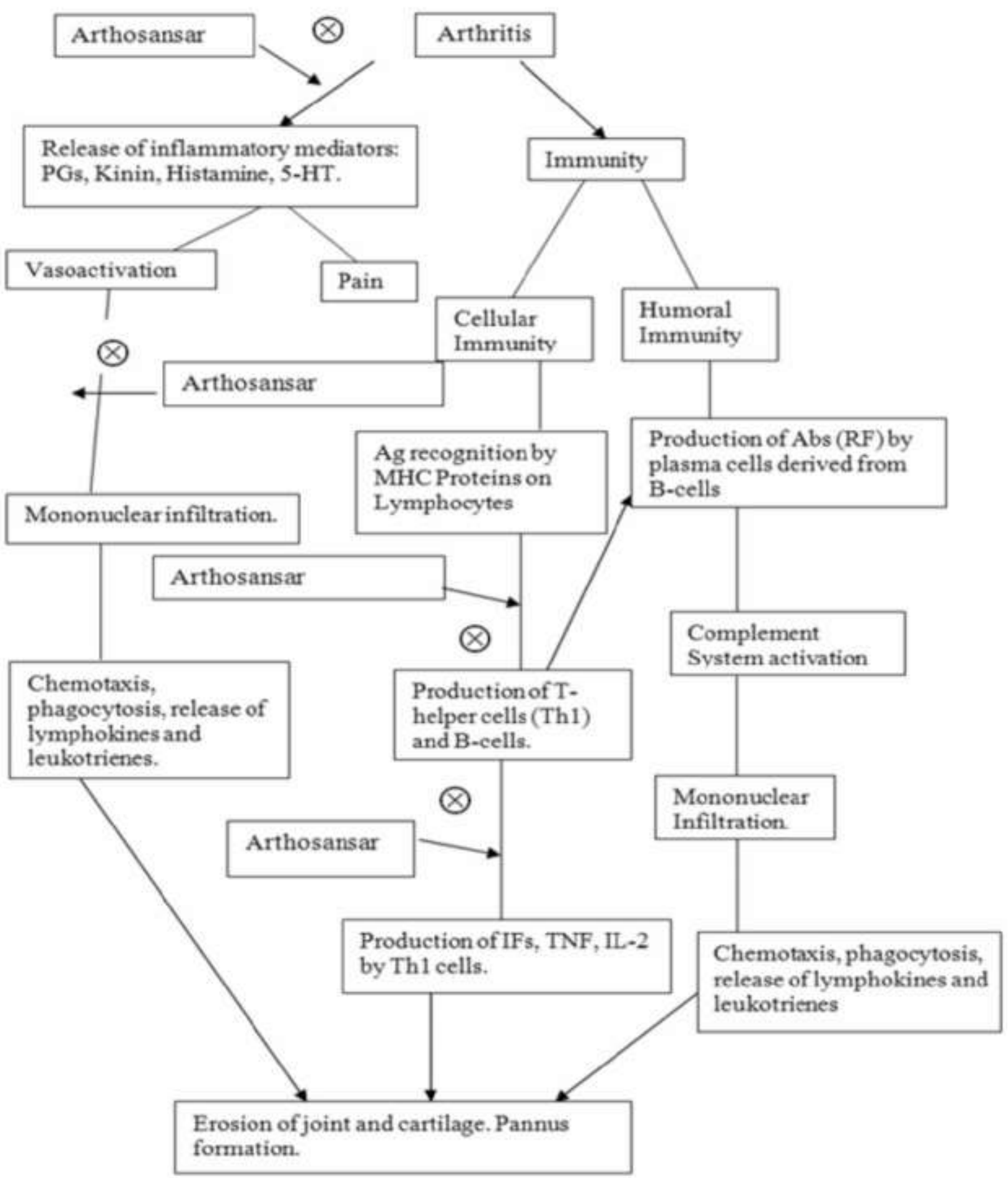

Figure 2 Mechanism of Arthosansar 


\section{Sudard}

Sudard is a poly-herbal formulation used in the therapy of RA. It consists extracts of 11 medicinal plants, which are as following Chandra sura (Lepidium sativum), Suranjan (Colchicum luteum), Dwipantra wacha (Smilax glabra), Kupilu (Strychnous nuxvomica), Guggulu (Commiphora mukul), Rasna (Pluchea lanceolata), Gandha Prasarini (Paederia foetida), Nirgundi (Vitex negundo), Ginger (Zingiber officinalis), Erandamula (Ricinus communis), and Shilajit (Mineral pitch). [39] The anti-inflammatory, analgesic, antiarthritis or anti-oxidant effects of these plants have been mentioned in the literature. The results of the present study show that the poly-herbal formulation sudard possesses significant anti-inflammatory, antiarthritic and analgesic activities in all the tested experimental models indicating inhibition of all phases of inflammation. The development of edema in the paw of the rat after injection of formalin and carrageen is a biphasic event. [40] Kinin is the one of major mediators of granuloma, as it both vasodilators and increase vascular permeability in the early stages of inflammation the effect of sudard on sub-acute inflammation confirmed that it inhibits the chemical mediators of inflammation. The central analgesic activity of this formulation was studied using hot plate method and peripheral activity was studied in acetic acid induced writhing test. [41] Sudard (150, $300 \mathrm{mg} / \mathrm{kg})$ significantly increased the reaction time in hot-plate test and also reduced the writhing response in mice injected with acetic acid. Hence, it is speculated that apart from inhibition of chemical mediators of inflammation, Sudard may also modulate the pain response in the central nervous system. [42] The other constituents of sudard; Pluchea lanceolata, Paederia foetida, Vitex negundo, Zingiber officinalis, Strychnos nuxvomica and Ricinus communis possess analgesic effect and also are effective in both acute and chronic inflammation. [43] Pluchea lanceolata is rich in volatile oil that contains methyl cinnamate, cineole, camphor and pinene. [44]Paederia foetida consists of volatile oils, alkaloids that include $\alpha$-paederine and $\beta$-paederine.[45] A number of constituents are known to be present in Vitex negundo which is known to contain alkaloids such as histidine and hydrocotylene, glocononitol hydroxyl isopthalic acid, benzoic acid, tannic acid, Agnesside, Oreintin, Iso-oreintin Aucubin, Casticin, and Glucoside of tetrahydroxy monomethyl flavone. Zingiber officinalis, commonly known as ginger contains zingerberol, borneol, linalool, geraniol, citral, gingerol, shogal, zingerone and resinous matter like starch mucilage. [46] Strychnos nuxvomica contains strychnine, brucin, strynic acid, vomicine and loganin. Ricinius communis which is the common castor seeds contains manly fixed oil which on hydrolysis yields ricinoleic acid. Other fatty acids present are iso-ricinoleic acid, stearic acid and iso-stearic acid. [47] The only constituent in Sudard that does not have any reported analgesic, anti-inflammatory or anti-arthritic effect is Lepidium sativum. However, this plant is reported to possess potent anti-oxidant effect. The anti-oxidant action may indirectly help in treatment of inflammation by scavenging free radicals. Lepidium sativum contains volatile oil that has variable 
proportion of benzyl isothiocyanate and benzyl cyanide. It also has alkaloids - glucotropucolin, sinapin and sinapic acid. [48] Other constituents include protein, fat, carbohydrate and trace elements; iron, nickel, cobalt and iodine. To conclude, the poly-herbal formulation 'sudard' possess good analgesic, antiinflammatory and anti-arthritic effects. [49]

Table 1some of polyherbal formulations which are studied for rheumatoid arthritis

\begin{tabular}{|c|c|c|}
\hline $\mathbf{S} / \mathbf{N}$ & $\begin{array}{c}\text { NAME OF } \\
\text { PHF }\end{array}$ & CONSTITUENT MEDICINAL PLANTS \\
\hline 1 & PG $201[50]$ & $\begin{array}{c}\text { Chaenomelis speciosa } C \text {. fructus } \\
\text { Achyranthes bibentata } \\
\text { Angelica senesis } \\
\text { Cnidium officianale } \\
\text { Gastrodiaelata Blume } \\
\text { Achanthopanacis cortyex } \\
\text { Carathamus tinctorius } L \\
\text { Cinnamomum } \\
\text { Aromaticumnees } \\
\text { Gentian macrophyll }\end{array}$ \\
\hline 2 & $\begin{array}{c}\text { Joint care B } \\
{[51]}\end{array}$ & $\begin{array}{c}\text { Alpiniagalanga } \\
\text { Commiphora wightii } \\
\text { Boswellia serrata } \\
\text { Foeniculum vulgare } \\
\text { Glycyrrhiza glabra } \\
\text { Vitexnegundo }\end{array}$ \\
\hline 3 & EASE@ [52] & $\begin{array}{c}\text { Cyperus rotundus } \\
\text { Tinospora cordifolia } \\
\text { Saussurea lappa } \\
\text { Picrorrhiza kurroa } \\
\text { Zingiber officinale }\end{array}$ \\
\hline 4 & $\begin{array}{c}\text { ARTICULIN F } \\
{[53]}\end{array}$ & $\begin{array}{l}\text { Withania somnifera } \\
\text { Curcuma longa } \\
\text { Boswellia serrata }\end{array}$ \\
\hline 5 & $\begin{array}{l}\text { COOL- } \\
\text { COOL (cool-X- } \\
\text { A) }[54]\end{array}$ & $\begin{array}{c}\text { Rhemania glutinosa } \\
\text { Achyranthus bidetata } \\
\text { Acanthopanax } \\
\text { Glycyrrhiza uralensis } \\
\text { Atractylodes macrocephalia } \\
\text { Penia fructuscens }\end{array}$ \\
\hline 6 & $\begin{array}{l}\text { QING LUO } \\
\text { YIN[55] }\end{array}$ & $\begin{array}{c}\text { Ginseng radix } \\
\text { Achyranthes radix } \\
\text { Eucommiae cortex } \\
\text { Astragalli radix }\end{array}$ \\
\hline
\end{tabular}




\begin{tabular}{|c|c|c|}
\hline 7 & OK 205 [56] & $\begin{array}{c}\text { Codenopsis pilosula } \\
\text { Nanal } \\
\text { Angelica koreane } \\
\text { Maxim } \\
\text { Acanthopanax } \\
\text { Chaenomeles sinesis } \\
\text { Kochne } \\
\text { Poriacocos } \\
\text { Glycyrrhiza uralensis }\end{array}$ \\
\hline 8 & $\begin{array}{c}\text { Dashanga } \\
\text { Ghana [57] }\end{array}$ & $\begin{array}{c}\text { Coleus vettiveroides } \\
\text { Saussurea lappa } \\
\text { Berberis aristata } \\
\text { Curcuma longa Linn. } \\
\text { Nardostachys grandiflora } \\
\text { Elettaria cardamomum (Linn) } \\
\text { Pterocarpus santalinus Linn. } \\
\text { Valeriana wallichii } \\
\text { Glycyrrhiza glabra Linn. } \\
\text { Albizia lebbeck }(\text { L).benth }\end{array}$ \\
\hline 9 & $\begin{array}{c}\text { Majoon } \\
\text { Suranjan } \\
\text { (commercially } \\
\text { available) [58] }\end{array}$ & $\begin{array}{c}\text { Piper negrum } \\
\text { Coriandrum sativum } \\
\text { Rosa Damascus } \\
\text { Origanum vulgare } \\
\text { Pyrethrum indicum. } \\
\text { Plumbago zelanicum. } \\
\text { communis oil } \\
\text { Foeniculum vulgare } \\
\text { Capparis spinosa } \\
\text { Terminalia chebula Ipomoea turpethum } \\
\text { Plumbago zelanicum } \\
\text { Verbas cumthapus } \\
\text { Ricinus communis oil }\end{array}$ \\
\hline 10 & BV-9238 [59] & $\begin{array}{c}\text { Apium graveolens } \\
\text { Zingiber officinalis } \\
\text { Convulvulus scammony } \\
\text { Colchicum luteum } \\
\text { Cassia angustifolia } \\
\text { Withania somnifera } \\
\text { Boswellia serrata } \\
\text { Zingiber officinale } \\
\text { Curcuma longa }\end{array}$ \\
\hline 11 & $\begin{array}{l}\text { DAI-BOFU- } \\
\text { TO(Kampo }\end{array}$ & $\begin{array}{c}\text { Glycyrrhiza radix Cnidiir hizome } \\
\text { Atractylodes } \\
\text { Ginseng radix Lancaea Acyranthus radix }\end{array}$ \\
\hline
\end{tabular}




\begin{tabular}{|l|c|}
\hline medicine) [60] & Zingiberisrhizoma \\
& Eucommiae cortex \\
& Paconia radix \\
& Notplergurhizoma \\
& Zizyphifructus \\
& Astragalli radix \\
& Aconiti \\
& Gichma radix Rehmannia \\
\hline
\end{tabular}




\section{Conclusion}

Although nowadays polyherbal formulations are being commonly used in different places in the world, but the scientific evidence is still lacking which limits the use of PHFs. Many herbal therapies are still under in-vivo evaluation studies, which are not tested by clinicians. PHFs lay out the treatment of diseases in a holistic approach. Nowadays, the world is curious about Ayurvedic PHFs due to its comparable efficacy, lesser side effects and better acceptability compared to allopathic drugs. Synergistic effect by use of combination of herbs is also an advantage of this formulation. Even the auto immune diseases can be better treated by this, as it subsides the symptoms causing little or no side effects. Currently scientist is exploring for development of new Polyherbal therapy or using old traditional polyherbal formulation which has been used in ancient times such as Ayurveda, whose history goes back to $5000 \mathrm{BC}$., is one of the health care systems. At present medicinal plants with ethno-medicinal values are screened for their therapeutic potential. There is need to evaluate polyherbal formulation by employing scientific methods for bioactive compounds and finding out its mechanism of action, further clinical trial, for the future world. Some models like Freund's complete adjuvant induced arthritis model are used to study the pathogenesis of arthritis for testing therapeutics and these models are characterized by a very rapid erosive disease. The bacterial peptidoglycan and muramyl dipeptide found in the FCA are accountable for the evocation of adjuvant arthritis. During study it was found that the arthritic rats exhibited a lower RBCs count, reduced $\mathrm{Hb}$ level and increased ESR levels. These symptoms suggest an anemic condition, which is a common diagnostic symptom in patients suffering from chronic arthritis. The ESR is the proportion of the number and size of the RBCs to the relative concentration of plasma proteins at a particular time, especially fibrinogen and $\beta$ globulins. An increase in the ESR count is a sign of active but doubtful disease processes. The acute phase proteins in ESR produce inflammation almost like that produced by an injection, injury, and surgery or tissue necrosis. The treatment followed with extracts increased the RBCs count, Hb level and ESR to a near-normal level, thus indicating a significant recovery from the anemic condition and arthritic progress, thus establishing that features a significant role in arthritic conditions.

White blood cells form significantly major component of the body's immune system. In arthritic conditions there is a mild to moderate increase in the WBC count. Prostaglandin and other cyclooxygenase products and various cells that are involved in inflammatory changes and free radical activities have all been implicated in the evolution of rat adjuvant arthritis. The radiographic analysis of the knee joint within the arthritic and drug-treated animals further supported and proved the potent dosedependent anti-arthritic effects. 
Ayurvedic medications are used for several decades for the treatment of varied ailments, but the underlying mechanism of action has not been clearly elucidated. Reports are available on the interactions of pure plant bioactive molecules with various inflammatory pathways but such studies just in case of Ayurvedic polyherbal formulations have seldom been reported. This study provides evidences of the mechanism by which a polyherbal Ayurvedic formulation inhibits the inflammatory pathways of cytokines and therefore the activity of lipoxygenase enzymes. It is possible that GTG exerts its anti-inflammatory property by inhibiting the pro-inflammatory cytokine production and therefore the lipoxygenase enzymatic pathway. The study showed that GTG is more efficient in inhibiting IL-1 $\beta$, which successively maybe responsible in controlling various immunological conditions. It is quite possible that a disease is caused thanks to multiple factors, cure of which might require treatment of multiple targets. Therefore, one drug with single target is not able to completely cure a diseased condition. Ayurveda, as an alternate sort of therapy uses polyherbal decoctions and ghritam with an outsized number of bioactive molecules which act synergistically at different targets to regulate a disease. 


\section{References}

1. Subramanian P. GanSiawThing and SokkalingamA.D. (2014). "Polyherbal formulation: Concept of Ayurveda". Pharmacogn. Rev. 8 (16): 73-80. Doi:10.4103/0973-7847.134229. PMC 4127824. PMID 25125878.

2. Goldman L. Cecil Medicine, Saunders,.Firestein, G. Kelley's' Textbook of Rheumatology', W.B. Saunders Company, 2008.

3. Majithia V, Geraci SA (November 2007). "Rheumatoid arthritis: diagnosis and management". The American Journal of Medicine. 120 (11): 936-9.

4. Turesson C. O'Fallon WM.Crowson CS. Gabriel SE. Matteson EL (August 2003). "Extra-articular disease manifestations in rheumatoid arthritis: incidence trends and risk factors over 46 years". Annals of the Rheumatic Diseases. 62 (8): 722-7. Doi:10.1136/ard.62.8.722. PMC 1754626. PMID 12860726.

5. Cutolo M. Kitas GD. van Riel PL (February 2014). "Burden of disease in treated rheumatoid arthritis patients: going beyond the joint". Seminars in Arthritis and Rheumatism. 43 (4): 479-88. Doi: 10.1016/j.semarthrit.2013.08.004. PMID 24080116.

6. Singh S. Nair V. Gupta YK. 'Antiarthritic Activity of majoonsuranjan (a polyherbal Unani formulation) in rat'. Indian J Med Res 2011; 134: 384-8.

7. Petchi R., Parasuraman S. and Kiran M.Ant 'arthritic activity of a Polyherbal formulation against Freund's complete adjuvant induced arthritis in Female' Wistarrats. June 2015 - August 2015; 6 (3) 77-83. https://www.ncbi.nlm.nih.gov/pmc/articles/PMC4513335/\#

8. Asad, Mohammed, Koteshwar Prasad, Licto Thomas, and Jagadish V. Kamath. "Evaluation of anti-arthritic and anti-inflammatory activity of Sudard, a poly herbal formulation." Iranian Journal of Pharmacology and Therapeutics 6, no. 1 (2007): 71-0

9. Anonymous (1978). 'The Ayurvedic Formulary of India. Ministry of Health and Family Welfare, Govt. of India', New Delhi. Pp-1-120.

10. Clarke TC Black LI, Stutsman BJ, Barnes PM, NahinRL'.Trends in the use of complementary health approaches among adults': United States, 2002-2012. National health statistics reports; no. 79. Hyattsville, MD: National Center for Health Statistics. 2015.

11. Cakrapaanidatta S. 'Ayurveda Dipikaa' (1984).Choukhambha SanskritaSanSthaana, Varanasi (India) Commentary on CarakSamhitaaCikitsa 3/197-199.

12. Saini M, Chaudhary A, Garg N, Jaiswal M L, Kotecha M. 'Rationality Behind Ayurveda Compound Formulations-A Bird's Eye View', IJAPR, 2016; 4:9.5.Ramachandra Rao, S.K. (1997).

13. Encyclopedia of Indian Medicine, Vol 2. Dr. P.V. Parameshvara Charitable trust, Bangalore. India.6.SiddhinandanMisra (1990). 'Ayurveda Rasashastra', second edition, ChoukhambhaOientalia,Delhi(India). P-7.

14. Anonymous. Indian Herbal Pharmacopoeia, Vol. II. A Joint Pub. Of RRL (CSIR) and IDMA (Mumbai), 1999; 58-66:162-173.

15. Gupta K A. 'Ashtanghrdyam Sutra sthan'Doshapkramaniyaadhyay. Varanasi: Chaukhambha Publications; 2009; p-131.

16. Patwardhan B. Bridging' Ayurveda with evidence-based scientific approaches in medicine.EPMA' Journal. 2014; $5(1): 19$.

17. Sharma P. V.'Charka Samhita: Vimansthan, Rasvimanadhyay' Varanasi: ChaukhambhaOrientalia Publications; 2005. Volume-1; p. 302. 
18. Vishnuprasad CN, Pradeep NS, Cho YW, Gangadharan GG, Han SS. 'Fumigation in Ayurveda: potential strategy for drug discovery and drug delivery". J Ethnopharmacol. 2013 Sep 16; 149(2):409-15. Doi: 10.1016/j.jep.2013.07.028. Epub 2013 Jul 29. PMID: 23906781.

19. Zhou Q., Zhou Y., Chen H., Wang Z., Tang Z., Liu J. The efficacy and safety of certolizumabpegol (CZP) in the treatment of active rheumatoid arthritis (RA): a meta-analysis from nine randomized controlled trials. Int $\mathrm{J}$ ClinExp Med. 2014; 7:3870-3880.Ishii K.J.1, Coban C., Kato H., Takahashi K., Torii Y., Takeshita F. Nat Immunol. 2006; 7(4):427. [Google Scholar].

20. Xu S., Lu H., Lin J., Chen Z., Jiang D., Woo J. "Regulation of TNF alpha and IL1beta in rheumatoid arthritis synovial fibroblasts by leukotrienes” B4. Rheumatol Int. 2011; 30(9):1183-1189. [Pub Med] [Google Scholar].

21. Simmonds R.E., Foxwell B.M. "Signalling, inflammation and arthritis: NF-kappa B and its relevance to arthritis and inflammation". Rheumatology (Oxford) 2008; 47(5):584-590. Doi: 10.1093/rheumatology/kem298. [Pub Med] [CrossRef] [Google Scholar].

22. Bijjiga E., Martino A.T. Interleukin 10 (IL-10) "regulatory cytokine and its clinical consequences". J Clin Cell Immunol. 2013; S1:007. Doi: 10.4172/2155-9899.S1-007. [CrossRef] [Google Scholar].

23. Ishii K.J.1, Coban C., Kato H., Takahashi K., Torii Y., Takeshita F. Nat Immunol. 2006; 7(4):427. [Google Scholar].

24. Xu S., Lu H., Lin J., Chen Z., Jiang D., Woo J. "Regulation of TNF alpha and IL1beta in rheumatoid arthritis synovial fibroblasts by leukotrienes” B4. Rheumatol Int. 2011; 30(9):1183-1189. [Pub Med] [Google Scholar].

25. Simmonds R.E., Foxwell B.M. "Signalling, inflammation and arthritis: NF-kappa B and its relevance to arthritis and inflammation". Rheumatology (Oxford) 2008; 47(5):584-590. Doi: 10.1093/rheumatology/kem298.

26. Bijjiga E., Martino A.T. Interleukin 10 (IL-10) "regulatory cytokine and its clinical consequence"s. J Clin Cell Immunol. 2013; S1:007. Doi: 10.4172/2155-9899.S1-007. [CrossRef] [Google Scholar].

27. Meera S, Kumar NS \&Guptatyam V, "Screening of anti Arthritic, anti inflammatory and analgesic activity of polyherbal Formulation”, Inter J Pharmacol, 4 (5) (2008) 398-402.

28. Harsh M, 'The Musculoskeletal system, In: “A text book Of Pathology”, $5^{\text {th }}$ edn, edited by Jaypee Brothers, Jaypee Brother Publishers, New Delhi), 2000, 487-90.

29. Hebbar KS, "Screening of anti-arthritic, anti-inflammatory and analgesic activity of polyherbal Formulation", (M. PharmDissertation, Rajiv Gandhi University of Health Sciences, Bangalore, Karnataka), 2010.

30. Vogel HG, In: "Drug discovery \& evaluation Pharmacological Assays", $2^{\text {nd }}$ edn. Edited by Vogel HG, co-editors Hock FJ, Mas J \& Meyer D, (Springer-verlag Berlin Heideberg, Germany), 2002, 697,716,753,802.

31. Carey WM, Dasi JMB, Rao NV \& Gottumukkala KM, "Anti-inflammatory activity of methanolic extract of Bambusa vulgaris leaves”, Int J Green Pharm, 35 (3) (2010) 197-9.

32. Mahat MA \&Patil BM, "Evaluation of anti-inflammatory Activity of methanol extract of Phyllanthusamarus in Experimental animal models”, Ind J Pharm Sci, 35 (8) (2007) 33-6.

33. Owoyele BV, Olaleye SB, Oke JM \&Elegbe RA, "Anti-inflammatory and analgesic activity of leaf extracts Of LandolphiaOwariensis", Afr J Biomed Res, 4 (2001) 131-3.

34. Rizzo DO, Disorders of Skeletal function: Rheumatic Disorder, "In: Pathophysiology-concepts of Altered Health State"s, $7^{\text {th }}$ edn. Edited by Perth CM, (Mc.Graw-Hill, New York), 2000, 1342.

35. Katzung BG, "In: Basic and Clinical Pharmacology, $7^{\text {th }}$ edn. Edited by Katzung BG", (Lange Medical books/McGraw-Hill, New York), 1998, 590.

36. Billiau A \&Matthys P, "Modes of action of Freunds Adjuvants in experimental models of autoimmune disease", J Leukocyte Biol, 70 (2001) 849-60. 
37. Rajkapoor B, Ravichandran V, Gobinath M, Anbu J, Harikrishnan N, et al., "Effect of Bauhinia veriegataOn complete Freundsadjuvant induced arthritis in rat"s,JPharmacolToxicol, 2 (5) (2007) 465-72.

38. Ekambaram S, Perumal SS \& Subramanian V, "Evaluation Ofant arthritic activity of Strychnospotatorum Linn seeds In freunds adjuvant induced arthritic rat mode"l, BMCComplemen Alter Med, 10 (56) (2010) 1-6.

39. Silva MD, Guginski G, Werner MF, Buggio CH, Marcon R, \& Santos ARS, "Involvement of IL-10 in the Antiinflammatory effect of Sanyinjiao (SP6) accupunture in A mouse model of peritonitis", Evidence-Based ComplemenAltern Med, 2011 (2011), Article ID 217946, doi:10.1093/Ecam/neq036

40. Souza ET, Lira DP, Queiroz AC, da silva DJC, AqinoAB, Mella EAC, et al., "The anti-nociceptive and AntiInflammatory activities of Caulerpin”, a Bisindoalkaloid isolated from seaweeds of the Genus Caulerpa, Mar Drugs, 7 (2009) 689-704.

41. Sharma JN. "Comparison of the anti-inflammatory activity of Commiphoramukul (an indigenous drug) with those of phenylbutazone and ibuprofen in experimental arthritis induced by mycobacterial adjuvant". Arzneimittelforschung 1977; 27:1455-7.

42. Kaith BS. "Neolupenol and Anti inflammatory Activity". Pharma-ceu Biol. 1996; 34: 73 - 75.

43. Srivastava MC, Tewari JP, Kant V. "Anti-inflammatory activity of an indigenous plant--Paederiafoetida “(Gandhali). Ind J Med Sci 1973; 27: 231-4.

44. Telang RS, Chatterjee S, Varshneya C. "Study on analgesic and anti-inflammatory activities of Vitexnegundo" Linn. Ind J Phar-macol. 1999; 31: 363-366.

45. Altman RD, Marcussen KC. "Effects of a ginger extract on knee pain in patients with osteoarthritis. Arthritis \& Rheumatism"44:2531 - 2538.

46. Ilavarasan R, Mallika M, Venkataraman S. "Anti-inflammatory and free radical scavenging activity of Ricinuscommunis root extract.” J Ethnopharmacol. 2006; 103: 478-80.

47. Greimel A, Koch H. "Peroxidase isoenzymes in cress seedlings (Lepidiumsativum L.) and their inhibition by silybin, silydianin and silychristin". Experientia 1977; 33: 1568-9.

48. Chopra RN, Nayar SL and Chopra IC. "Glossary of Indian Medicinal Plants (Including the Supplement). Council of Scientific and Industrial Research”, New Delhi 1986.

49. Jiang J., Xu Q. "Immunomodulatory activity of the aqueous extract from rhizome of Smilax glabra in the later phase of adjuvant-induced arthritis in rats". J Ethnopharmacol. 2003; 85: 53-9.

50. WH, Y.Yoo HG, Park SH, Baek HJ, Lee YJ, Shim SC, Kang SW, Kim HA, Song JS, Suh CH, Choi SJ, Yoon BY, Tae DN, Ko HS, Song YW. "Efficacy and safety of PG201 (Layla(®)) and celecoxib in the treatment of symptomatic knee osteoarthritis: a double-blinded, randomized, multi-center, active drug comparative, parallelgroup, non-inferiority, phase III study”. Rheumatol Int. 2014 Oct;34(10):1369-78. Doi: 10.1007/s00296-0142964-8. Epub 2014 Feb 16. PMID: 24531687.

51. Matsuda H, Pongpiriyadacha Y, Morikawa T, Ochi M, Yoshikawa M. "Gastroprotective of phenyl propanoids from the rhizomes of Alpiniagalanga in rats: Structural requirements and mode of action". Eur J Pharmacol2003;47:59-6.

52. Okoli C O Akah P A and Nwafor S V “Anti-inflammatory activity of plants," Journal of Natural Remedies, vol. 3, no. 1, pp. 1-30, 2003.

53. Soeken K L Miller S A "Herbal medicines for the treatment of rheumatoid arthritis: a systematic review," Rheumatology, vol. 42, no. 5, pp. 652-659, 2003.

54. Rao J KMihaliak K. Kroenke J. Bradley W M. and Weinberger M "Use of complementary therapies for arthritis among patients of rheumatologists," Annals of Internal Medicine, vol. 131, no. 6, pp. 409-416, 1999. 
55. Li S, Lu AP, Wang YY, Li YD. "Suppressive effects of a Chinese herbal medicine qing-luo-yin extract on the angiogenesis of collagen-induced arthritis in rats". Am J Chin Med. 2003;31(5):713-20. Doi: 10.1142/S0192415X03001430. PMID: 14696674.

56. Tang C., Ding R., Sun J., Liu J., Kan J., Jin C.H. "The impacts of natural polysaccharides on the intestinal microbiota and immune responses-A review”. Food Funct. 2019 doi: 10.1039/C8FO01946K.

57. Galib R, Patgiri B J Prajapati P K Ashok B K and Ravishankar B Toxicol Int. 2015 Jan-Apr; 22(1): 141-146.doi: 10.4103/0971-6580.172279PMCID: PMC4721162PMID: 26862275.

58. Singh S, Nair V, Gupta YK. "Ant arthritic activity of majoonsuranjan (a polyherbal Unani formulation) in rat". Indian J Med Res. 2011 Sep;134(3):384-8. PMID: 21985823; PMCID: PMC3193721.

59. Dey D, Chaskar S, Athavale N, Chitre D. "Inhibition of LPS-induced TNF- $\alpha$ and NO production in mouse macrophage and inflammatory response in rat animal models by a novel Ayurvedic formulation”, BV-9238. Phytother Res. 2014 Oct;28(10):1479-85. Doi: 10.1002/ptr.5151. Epub 2014 Apr 7. PMID: 24706581.

60. Inoue M, Ono Y, Mizukami H. "Suppressive effect of Dai-bofu-to on collagen-induced arthritis". Biol Pharm Bull. 2004 Jun;27(6):857-62. Doi: 10.1248/bpb.27.857. PMID: 15187433. 